Variations tibétaines, Et autres...

Donatas Brandišauskas, Leaving Footprints in the Taiga: Enacted and Emplaced Power and Luck among Orochen-Evenki of the Zabaikal region in Eastern Siberia

\title{
OpenEdition
}

Electronic version

URL: https://journals.openedition.org/emscat/1941

DOI: 10.4000/emscat. 1941

ISSN: 2101-0013

Publisher

Centre d'Etudes Mongoles \& Sibériennes / École Pratique des Hautes Études

Electronic reference

"Donatas Brandišauskas, Leaving Footprints in the Taiga: Enacted and Emplaced Power and Luck among Orochen-Evenki of the Zabaikal region in Eastern Siberia", Études mongoles et sibériennes, centrasiatiques et tibétaines [Online], 42 | 2011, Online since 20 December 2011, connection on 13 July 2021. URL: http://journals.openedition.org/emscat/1941 ; DOI: https://doi.org/10.4000/emscat.1941

This text was automatically generated on 13 July 2021.

(c) Tous droits réservés 


\section{Donatas Brandišauskas, Leaving Footprints in the Taiga: Enacted and Emplaced Power and Luck among Orochen-Evenki of the Zabaikal region in Eastern Siberia}

\section{REFERENCES}

Vytautas Magnus University, University of Aberdeen, Draft, August 2009

My dissertation is an ethnographic study of a group of Orochen-Evenki hunters and reindeer herders inhabiting the northern taiga of the Zabaikal region of Eastern Siberia. The study is the result of 15 months of fieldwork conducted in Zabaikal County as well as in Buriatiia in 2004-2005. I investigated how the Orochen-Evenki organize their subsistence activities in a post-Soviet environment of a shortage of and competition for resources. I focus on the ways small Orochen communities have adapted their hunting and herding activities in the face of complex social, economic, ecological and political changes. Primarily, my research was on the widely known, but little studied, concept of 'mastery' in ethnographic literature on Siberia. We find in Russian ethnographical literature, such as the comparative studies of Siberians carried out by Alekseev 1975, Zelenin 1929, Gurvich 1977, Mihailov 1987 and Petri 1930 that 'master' (R. hoziain) is at the same time defined as a spirit (R. dukh) or an animal that rules different places or to a spirit which resides in crafted material objects. According to these authors, such a master-spirit (R. duh hoziain) is in charge of different geographic locations which have an influence on wild and domesticated animals and may shape human destinies. Other authors (Anisimov 1963, Shirokogoroff 1935) limit their definition of 'mastery' to shamanic abilities to dominate spirits and to achieve desired results in healing or fighting against evil spirits while protecting their own 
clan. Several Russian ethnographers (Vasilevich 1969, Varlamova 2004) describe the vernacular Evenki notion of musun as being linkedt to ideas of 'strength' (R. sila), 'energy' (R. energiia) and 'movement' (R. dvizhenie) intrinsic to different living beings, material objects and spoken words. Vasilevich $(1969$, p. 228) states that the early term musun was developed by the Orochen to mean personalized entities such as different strong master-spirits or shamans in the evolution of images as in those in the Evenki religion. While Varlamova (2004, pp. 59-60) describes how the interactions of the Orochen of the Amur region with different objects that contain musun bring luck and healing to people, she also notes that negative human actions can kill the musun of different objects (ibid).

In my dissertation, I investigate the complexity of the vernacular Orochen term ezhen that is translated by the Orochen as 'master' (R. hoziain) (see Tsintsius' 1975, pp. 437-438). 'Mastery' as employed in my dissertation describes relational forms of Orochen power intrinsic to interactions among humans, animals and spirits associated with different places and material objects. Orochen hunters and herders describe ezhen as a person with qualities of 'mightiness' (R. mogushchii) or 'strength' (R. silnyi) that can be exercised in practice. Orochen hunters and herders refer to mastery through the notion of chinen, defined as 'spiritual strength' (R. duhovnaia sila), 'energy' (R. energiia), 'capability' (R. umenie), 'physical strength' (R. fizicheskaia sila) and 'strength of movement' (R. sila dvizhenie). ${ }^{2}$ Such strength can be exercised by hunters and herders to achieve success in daily practices of subsistence. Hence, in the dissertation I analyze how luck in hunting and herding is achieved through one's skills, ritual practices, and knowledge, gained through multisensory awareness and empathy, dreams and divinations while competing with other beings (humans, animals and spirits).

3 Success in subsistence can be achieved through complex power interactions (cooperation and aggression) with humans, animals, and spirits when dwelling in different places in the taiga. The Orochen often describe their success as 'luck' (O. kutu, $R$. fart, udacha) that is attained because of the generosity of a master-spirit as well as through the successful use of one's knowledge and skills in harvesting game animals. Such success is based on outsmarting animals as well as fulfilling moral responsibilities to animals (proper ways of hunting, treatment of bones or talking about animals) and feeding master-spirits with offerings. These interactions are seen by hunters and herders as the proper way of subsisting while cooperating with master-spirits and maintaining well-being (R. blagopoluchie). I also provide several examples of mastery that reveal a mixture of cooperationand aggression. In addition I discuss what the Orochen consider to be occasional aggression in order to achieve success in harvesting game in an environment of shortage and competition. Usually this action is seen by the Orochen as being negative and is considered an aggressive strategy that is expressed through the notions of 'sin' (O. ngelome, R. greh) or 'poaching' (R. brakonerstvo). ${ }^{3} \mathrm{The}$ Orochen believe that sins can generate an aggressive reciprocal reaction from other animals or master-spirits living in the taiga, since these beings might attack a 'sinful person' (R. greshnik). Such a sinful person loses hunting 'luck', because he/she has no master-spirit support. Nevertheless, he/she can continue to achieve success in harvesting animals through aggressive strategies.

4 In my research, I open a critical exploration of the ways 'power' has been defined in circumpolar literature as the ability to accomplish one's goals by oneself without compelling anyone else to act in a certain way (Goulet 1998, Feit 1986, Ridington 1988, 
Sharp 2001). I argue that Orochen power interaction can be analyzed as a possibility to either cooperate with master-spirits, humans and animals or as a aggression enacted against other humans, animals and spirits. Hence, humans can feed master-spirits cooperating with them as well as compel animals or other spirits to act in certain ways, by using aggressive practices. Generally speaking, the ethnographic literature on circumpolar people has failed to represent this mixture of cooperation and aggression that characterizes the Orochen's as well as other circumpolar people's relations to their environment (including humans, non-humans and places). These ethnographies tend to describe human-animal relations as antithetical models of reciprocity and domination (Brightman 2002, Tanner 1979, Willerslev 2007). I show that aggression and cooperation can be seen as part of reciprocal relations in Orochen interactions with other beings, as referred to in the work of Mauss (1967). For hunters and herders any activity of cooperation and aggression might trigger an equivalent reaction from master-spirits.

In my dissertation, I show that acts of aggression and cooperation create a lot of anxiety, ambiguity and doubt for the Orochen in the post-Soviet environment of competition for and a shortage of resources. Hunters and herders believe that cooperation with master-spirits also imposes some 'limits' (R. ogranichenie) on hunting results. The Orochen say that a master-spirit tries to keep the balance between animals dwelling in different places and therefore he gives them just enough for their daily needs (R. tol'ko dlia prozhivania), but not to build up wealth (R. ne na bogatsvo). Thus, one has to rely uniquely on the 'goodwill' of the master-spirits (R. chto hoziain dast). Therefore, the Orochen believe that their cooperation with master-spirits might sometimes result in a lack of meat or fur for a certain period. In such a context, humans might rely on aggression through forcing their will on another human and non-human, or by 'spoiling the luck' of others (R. napakostit' fart). This is a way one increases one's chances to achieve success in subsistence. According to hunters and herders, if someone acts aggressively, they will most probably succeed in harvesting game animals, but the soul of the prey or the master-spirit may attack them. Hence, I also describe how hunters and herders obtain and maintain success and well-being, concealing their future plans, present and past activities from other contesting beings. They also try to act aggressively hiding these actions and misleading master-spirits with the aim of escaping from their attacks.

6 In addition, I show how mastery can be analyzed through Orochen perceptions, experiences and uses of different taiga places. After the collapse of the Soviet system, the Orochen had the opportunity to privatize reindeer from the state farms as well as to appropriate collective farms' territories for herding and hunting. Now going to places where no rituals of respect had been performed for half a century during the Soviet era, herders and hunters are confronted with master-spirits and arenki $i^{4}$, who had been neglected during that period. Hunters and herders experience how former dwelling places, sites of ritual practices or places of tragic events continue to affect contemporary humans' lives. Hunters and herders believe that these places can contain 'bad energy' (R. plohuiu energiiu) ${ }^{5}$ or can be inhabited by evil spirits. It can be dangerous for people to dwell in these places unless one establishes cooperation with a spirit through gifts and offerings during rituals. If someone has to avoid a place then they will suffer from a shortage of territory to hunt and herd animals. If somebody succeeds in cooperating with master-spirits then they maintain well-being while dwelling there for a long time. Dwelling and having activities in a place for a long time brings a new identity to the place. People believe that old camps are places that contain the energy 
(R. energiia) of people who used certain places for their own subsistence. Hence, these places may affect the activities of people alive now by the simple fact that they use these places. In this context, Orochen hunters and herders see old camps, places of rock art, crafted items as well as newly created tangible ritual sites as containing the strength of humans or non-humans who used them in the past or continue to use them now.

7 After the collapse of the centralized economy, many villagers rushed to the taiga to harvest resources, competing among themselves for hunting or herding grounds as well as for different opportunities of subsistence. In the unstable post-Soviet environment, for the Orochen success is based on one's abilities to create networks of reciprocity with other humans, animals and master-spirits. It also depends on how one uses different skills and knowledge for subsistence in the taiga. Skills and knowledge for subsistence also include covert strategies (that is to say trying to hide one's activities in the taiga), discourses, public ritual performances and the creation of tangible ritual sites to protect one's well-being (R. blagopoluchie). Today, the Orochen strive to be masters of different places or domestic animals in different ways: by maintaining luck and well-being in subsistence, by cooperating with non-humans or by achieving success through aggression in an environment of competition.

Thus, the chapters of my dissertation are devoted to the themes of mastery through a series of interrelated ethnographic case studies. In the introductory chapter, I analyze notions of 'mastery', 'luck', 'strength', 'aggression and cooperation', 'competition' found in classic Russian ethnographies. I describe Orochen 'mastery' (O. ezhen) and 'strength' (O. chinen) and compare them to the notion of 'power' found in worldwide circumpolar societies. Chapter 2 introduces how the Russian state dominated the lives of indigenous people through early colonial policies, administrative changes, and Soviet reforms. I outline the dramatic history of how they disrupted Orochen land-use and subsistence practices and how people responded to these policies. This chapter provides the environmental and social context of the dissertation. Chapter 3 introduces informants, the fieldwork itinerary, data collecting strategies, and explains the difficulties faced during my fieldwork. I describe how I developed skills and acquired knowledge while being an apprentice of hunters and herders in different places in the taiga. I also describe how the adjustment of my activities and discursive practices of the life of hunters and herders aimed to maintain the luck of the people I was living with as well as helping build trust. Chapter 4 focuses on how Orochen hunters and herders achieve success in hunting. It goes into detail on how they compete with animals through their tracking skills and their knowledge of animals' living places(O. bikit). ${ }^{6}$ Hunters claim to cooperate with master-spirits through daily offerings to maintain luck and well-being. However, they also experience limits to their hunting success, since master-spirits only give some animals controlling balance of animals in different places. Therefore, hunters turn to aggressive activities referred to as poaching ( $R$. brakonerstvo) to harvest game animals. Chapter 5 describes ambivalent human interactions with domestic animals (reindeer and dogs) as well as predators (bears and wolves) in the context of a shortage of and competition for land in the post-Soviet environment. Chapter 6 examines the mastery linked to successful prediction and influence on the weather. I show how one adjusts one's movements based on one's knowledge of the weather to ensure the best use of different hunting areas and subsistence. Chapter 7 looks at how hunters and herders adjust their use of permanent dwellings and camps to the local landscape by being aware of wild and domesticated 
animals living nearby as well as of spirits dwelling in different places. Chapter 8 describes how walking is considered an important skill, but also a strength and a moral value leading to success in Orochen daily practices of subsistence. I describe walking through Orochen metaphorical representations, linking it to the competence and contrasting it with the pejorative colonial concept of the 'Walking Tungus'. Walking and the use of signs and paths are important for the cooperation and the autonomy of herders dwelling in remote taiga areas. Chapter 9 goes into further detail on the way hunters and herders cooperate with the aim of maintaining autonomy through the accumulation of goods and storing supplies in an environment of mistrust. I show how different forms of cooperation vary according to experiences of luck, trust, and forms of exchange between different individuals. Chapter 10 explores the daily rituals that are connected to aggression and cooperation. These rituals are used when people are in competition with other beings as well as in interaction with master-spirits. This chapter also describes the role of places linked to master-spirits, public rituals and the creation of tangible ritual sites for the Orochen community striving to achieve wellbeing and gain luck. My concluding chapter summarises my main ideas outlined in each chapter and analyzes mastery as a crucial concept for the Orochen of power interactions with other beings. I show that mastery embraces vernacular notions of strength and luck. These power interactions based on cooperation and aggression are also guided by reciprocal interactions and can also be analyzed through Orochen perception and use of different places. In addition, the chapter outlines how the thesis has made an academic contribution to our more general understanding of power interactions in Siberia and in the circumpolar North. It shows that hunter relations with wild and domesticated animals and spirits take us far beyond ideas that spirits or animals are generous as long as they are treated with respect. It suggests that interactions between different beings embrace both aggression and cooperation as well as feelings of anxiety, ambiguity and doubt.

9 The Orochen-Evenki of the Zabaikal'e suffered some of the most drastic reforms and reprisals of any region in Siberia during the Tsarist era and Soviet times. My dissertation aims to fill an ethnographic gap by describing communities that have scarcely been studied since Russian émigré ethnographer Sergei Shirokogoroff's classic works in the early $20^{\text {th }}$ century. Shirokogoroff (1935) in his famous work, based on research of the Orochen of Amur, Manchuria as well as the Zabaikal region, aimed to study the Orochen 'psycho-mental complex' by describing the variety of interactions of shamans (mainly domination) with animals and groups of spirits in different places and 'placings'. ' Shirokogoroff conducted his fieldwork among the Orochen in the dramatic environment of civil war. In the unstable post-Soviet environment, one might not be surprised to find how many old forms of rituals are found creatively re-enacted among the Orochen (see also Anderson in press). Mastery of spirits can be attributed not only to the coercive activities of shamans against spirits as was implied by Shirokogoroff (1935). I show that mastery might be based on cooperation, such as feeding masterspirits and following moral responsibilities, as well as on aggression, compelling other beings through rituals and discourses of any Orochen hunter and herder. Hence, the ways people use to secure mastery of places and of other beings can be analyzed by looking at daily strategies, skills and knowledge of subsistence such as camping, walking, storing practices, tracking, relying on informal networks of cooperation while aiming to achieve luck in hunting and herding. Ritual practices carried out by and for individuals as well as for the whole community serve to maintain their identity as one 
of being linked to life in the taiga and for claims on the land. Thereby, my dissertation reveals the Orochens' flexibility and skills for adapting to changing economic and political circumstances as well as to the shift of seasons and the movements of animals in the taiga. The ability of hunters and herders to adjust their daily practices and create networks of reciprocity with other beings so that they have the best opportunities for subsistence in different taiga places are at the heart of Orochen mastery.

\section{BIBLIOGRAPHY}

Alekseev, N. A.

1975 Traditsionnye religioznye verovaniia iakutov v XIX - nachale XX v. (Novosibirsk, Nauka).

Anisimov, A. F.

1963 The shaman's tent of the Evenki and the origins of shamanistic rite, in H.N. Michael (ed.), Studies in Siberian shamanism (Toronto, University of Toronto Press), pp. 84-123.

Anderson, D. G.

(In press) Neo-Shamanism in a Post-Socialist Landscape: Knowledge, Luck and Ritual Among Zabaikal' Orochen-Evenkis, in Peter Jordan (ed), Landscape and Culture in Northern Eurasia (Walnut Creek CA, Left Coast Press).

Brightman, R. A.

2002 Grateful Prey: Rock Cree Animal-Human Relationships (Regina, Canadian Plains Research Centre).

Feit, H. A.

1986 Hunting and the quest for Power: The James Bay Cree and Whitemen in the Twentieth Century, in Morrison B. R. and C. R. Wilson (ed.), Native peoples: Canadian experience (Toronto, McClelland \& Stewart), pp. 171-207.

Goulet, J. G.

1998 Ways of Knowing: Experience, Knowledge, and Power among the Dene Tha (Lincoln, University of Nebraska Press).

Gurvich, I. S.

1977 Kul'tura severnyh iakutov-olenevodov (Moskva, Nauka).

Halemba, A. E.

2007 The Telengits of Southern Siberia (London, New York, Routledge Press).

Humphrey, C.

1996 Shamans and Elders: Experience, knowledge, and power among the Daur Mongols (Oxford, Oxford University Press).

Mauss, M.

1967 The Gift: Forms and functions of exchange in archaic society (New York, WW Norton).

Mikhailov, T. M.

1987 Buriatskii shamanism: istoriia, struktura i sotsialnye funktsii (Novosibirsk, Nauka). 
Petri, B. E.

1930 Ohota i olenevostvo u tuturskih Tungusov v sviazi s organizatsiei ohothoziaistva (Irkutsk).

Ridington, $\mathrm{R}$.

1988 Knowledge, power and the individual in Subarctic hunting societies, American Anthropologist

90 (1), pp. 98-110.

Sharp, H. S.

2001 Loon: memory, meaning, and reality in a northern Dene community (Lincoln, University of Nebraska press).

Shirokogoroff, S. M.

1935 Psychomental complex of the Tungus (London, Kegan Paul, Trench, Trubner and Co. Ltd).

Tanner, A.

1979 Bringing home animals: religious ideology and mode of production of the Mistassini Cree hunters, Social and Economic Studies, 23 (St. Johns, Institute of Social and Economic Research).

Titov, E. I.

1926b Tunguskii-Russkii slovar' (Irkutsk, Vlast' Truda).

Tsintsius, V. I.

1975 Sravnitel'nii slovar Tunguso-Man'chzhurskih iazykov (Leningrad, Nauka), T. 1-2.

Varlamova, G. I.

2004 Mirovozrenie evenkov: otrazhenie $v$ folklore (Novosibirsk, Nauka).

Vasilevich, G. M.

1969 Evenki: Istoriko-etnograficheskie ocherki (XVIII-nachalo XX v.) (Leningrad, Nauka).

Willerslev, R.

2007 Soul hunters: hunting, animism, and personhood among the Siberian Yukaghirs. (Berkeley, Los Angeles, London, University of California Press).

Zelenin, D. K.

1929 Tabu slov u narodov Vostochnoi Evropy i Severnoi Azii, Sbornik Muzeia antropologii i etnografii, 8 (Leningrad, SMAE).

Znamenski, A. A.

2007 The Beauty of the Primitive: Shamanism and the Western Imagination (Oxford, Oxford University Press).

\section{NOTES}

1. We can find that ezhen among Turkic speakers is translated as 'mastery' and 'power', conferring this quality to places, spirits as well as humans (eeze among Altaians in Halemba 2007, pp. 64-67, eze among Mongolians in Humphrey 1996, pp. 85-86).

2. We can also find in Tsintsius' (see 1975: 396-397) dictionary that the term chinen is translated as 'might' (R. mosch'), 'strength' (R. sila), as well as 'strong person' (R. bogatyr') and 'chief' (R. vozhd') (for more on ezhen/ozhen and chinen see dictionary of Titov 1926, p. 112, 171).

3. The vernacular conceptions of poaching as used by hunters and herders contrast with the formal regulations describing poaching as hunting without formal permission or a license. The Orochen perceive poaching as an 'unequal contest' (R. na ravne) using elaborate hunting equipment, wasting animals, being 'disrespectful to animals' remains and leaving places of butchering 'untidy' that might 'spoil' luck for other humans and animals. 
4. The Orochen define the spirit arenki as the soul of hunters or herders that did not reach the world of dead because of sudden or accidental death or because souls were not transported there by rituals. These souls can be benevolent or malevolent.

5. My main informant Nikolai Aruneev, who was familiar with New Age literature, preferred to use the word energiia rather than strength- R. sila (see also Znamenski 2007, p. 354).

6. Orochen hunters and herders often use the word bikit to describe the living place of an animal (or a group of animals) such as a wolf, bear, sable, squirrel, rabbit or domesticated reindeer (see for bikit Tsintsius 1975, p. 79). Bikit is a place of intense and sustained animal activity.

7. Shirokogoroff (1935, pp. 149-150) writes that some spirits can enter and exit different 'placings' independently as well as being invited or enticed by humans to enter specific objects which are then kept for their own needs. This type of 'placing' can be described as an emplaced form of spirit. Therefore, any geographical location, tree, animal, human, crafted item, or part of an organ can become such a 'placing'. 